\title{
ANALISIS MAQASID AL-TASARRUFAT AL-MALIYYAH MUHAMMAD AL-TAHIR IBN ASHUR TERHADAP AKAD $A L$-IJARAH AL-MUNTAHIYAH BI AL-TAMLIK (STUDI PADA PT. BRI SYARIAH KCP PONOROGO)
}

\author{
Mohammad Ridwan \\ Institut Agama Islam Negeri Ponorogo, Indonesia \\ rid1ahmad665@gmail.com
}

\begin{abstract}
The writing aims: (1) to find an assessment to measure the level of bank compliance with the contract al-Ijarah al-Muntahiya bi al-Tamlik (IMBT) based on maqasid al-tasarrufat al-maliyyah the idea of al-Tahir ibn 'Ashu $r$, (2) to reveals the phenomenon of BRI Syariah KCP Ponorogo compliance with the IMBT contract. The research method used is a qualitative method with a case study type. The type of data in this research is qualitative data on the words and actions of the research subject. Data collection techniques used documentation and unstructured planned interviews. Technique of checking data through credibility test and dependability test. The data analysis technique used Miles and Huberman's analysis with data reduction, data presentation, and conclusion drawing. To make an assessment of the suitability of Islamic banks using the Sekaran method to operationalize maqasid al-tasarrufat al-maliyyah the idea of al-Tahir ibn 'Ashur into dimensions and elements. To develop measurement indicators using the DSN-MUI fatwa. Meanwhile, to obtain a score of compliance with Islamic banks using the balanced scorecard method calculation technique. The findings of this research are BRI Syariah KCP Ponorogo complies with the sharia provisions in the IMBT contract based on maqasid al-tasarrufat almaliyyah ideas al-Tahir ibn 'Ashur. The level of compliance is $72.5 \%$ with the fulfillment of circulation goals of $70 \%$, transparency $68.75 \%$, strength of law $80 \%$, preservation of $75 \%$, and justice $68.75 \%$. This study contributes to a qualitative assessment of sharia compliance based on maqasid al-tasarrufat al-maliyyah ideas al-Tahir ibn 'Ashur as a standard or parameter to assess adherence. Islamic banks in channeling IMBT financing.
\end{abstract}

Keywords: Maqasid al-Tasarrufat al-Maliyyah, Akad, al-Ijarah al-Muntahiyah bi al-Tamlik

Abstrak: Penelitian ini bertujuan: (1) menemukan assesmen untuk mengukur tingkat kepatuhan bank terhadap akad al-Ijarah al-Muntahiya bi al-Tamlik (IMBT) berdasarkan maqasid al-tasarrufat al-maliyyah gagasan al-Tahir ibn 'Ashur, (2) mengungkap fenomena kepatuhan BRI Syariah KCP Ponorogo terhadap akad IMBT. Metode penelitian yang digunakan adalah metode kualitatif dengan tipe studi kasus. Jenis data penelitian ini adalah data kualitatif kata-kata dan tindakan subjek penelitian. Teknik pengumpulan data menggunakan dokumentasi dan wawancara terencana tidak terstruktur. Teknik pemeriksaan data melalui uji kredibilitas dan uji dependibilitas. Teknik analisis data menggunakan analisis Miles dan Huberman dengan reduksi data, penyajian data, dan pengambilan kesimpulan. Untuk membuat assesmen kesesuaian bank syariah menggunakan metode Sekaran untuk mengoperasionalisasi maqasid al-tasarrufat al-maliyyah gagasan al-Tahir ibn 'Ashur menjadi dimensi dan elemen. Untuk mengembangkan indikator pengukuran menggunakan fatwa DSN-MUI. Sedangkan untuk memperoleh skor kepatuhan bank syariah menggunakan Teknik 
perhitungan metode balanced scorecard. Temuan penelitian ini adalah BRI Syariah KCP Ponorogo patuh terhadap ketentuan syariah dalam akad IMBT berdasarkan maqasid altasarrufat al-maliyyah gagasan al-Tahir ibn 'Ashur. Tingkat kepatuhannya sebesar $72.5 \%$ dengan pemenuhan tujuan sirkulasi $70 \%$, transparansi $68.75 \%$, kekuatan hukum $80 \%$, preservasi $75 \%$, dan keadilan $68.75 \%$. Penelitian ini berkontribusi pada assesmen kepatuhan syariah secara kualitatif berdasarkan maqasid al-tasarrufat al-maliyyah gagasan al-Tahir ibn 'Ashur sebagai standar atau parameter untuk menilai kepatuhan Bank syariah dalam menyalurkan pembiayaan IMBT.

Kata Kunci: Maqasid al-Tasarrufat al-Maliyyah, Akad, al-Ijarah al-Muntahiyah bi alTamlik

\section{PENDAHULUAN}

Lembaga keuangan yang sangat berpengaruh terhadap perekonomian masyarakat di suatu negara adalah perbankan. Bank menjadi lembaga keuangan yang mewadahi berbagai pihak, baik perusahaan swasta maupun perorangan dan badan-badan pemerintah untuk menyimpan dananya. Melalui kegiatan, pembiayaan, pinjaman, perkreditan, dan berbagai jasa lain yang ditawarkan oleh bank, sehingga seiring berjalannya waktu, bank telah menjadi sebuah kebutuhan hidup bagi masyarakat di suatu negara (Sulhan \& Siswanto, 2008).

Kehadiran bank syariah di Indonesia semenjak tahun 1991 memberikan alternatif pilihan bagi masyarakat yang menginginkan bebas dari bunga ketika bertransaksi dengan perbankan. Bank syariah menawarkan sistem perbankan yang berbeda dengan bank konvensional, yaitu sistem syariah yang menghilangkan riba, garar, dan maysir yang dianggap haram oleh umat Islam pada semua aspek, baik transaksi, produk, maupun operasional. Sebagai gantinya, bank syariah menerapakan prinsip jual beli, bagi hasil, dan sewa menyewa dalam aplikasi produk-produk perbankan agar sesuai dengan ketentuan syariah dalam bidang muamalah. Semenjak awal kehadirannya di Indonesia, bank syariah belum menunjukkan perkembangan yang menggembirakan dari sisi pertumbuhan bisnisnya. Salah satu persoalan yang dapat menghambat pertumbuhan bank syariah di Indonesia adalah pemahaman dan kesadaran masyarakat yang masih rendah mengenai bank syariah (Aditiasari, 2019).

Rendahnya kesadaran masyarakat Indonesia untuk bertransaksi dengan bank syariah bukan disebabkan persoalan teknis seperti layanan, jaringan kantor, produk, dan lain-lain, tapi lebih kepada persoalan non teknis yaitu kurangnya pemahaman yang benar dan utuh dari masyarakat tentang praktik sistem keuangan syariah yang dijalankan oleh bank syariah. Hal ini berdampak pada munculnya keraguan dan keengganan bahkan tudingan 
JoIE: Journal of Islamic Economics I Mohammad Ridwan

P-ISSN: $2807-7377$

E-ISSN: 2807-7091

miring yang dilontarkan dari sebagian orang bahwa bank syariah sama saja dengan bank konvensional bedanya hanya pada istilah, bank syariah masih mengandung riba, dan bank syariah dianggap menyimpang dari ketentuan syariah dalam operasionalisasi produk-produk penghimpunan dan penyaluran dana (Zen Ibrahim, 2019).

Produk-produk pembiayaan di perbankan syariah diantaranya pembiayaan berdasarkan prinsip bagi hasil, pembiayaan dengan prinsip jual-beli dan pembiayaan dengan prinsip sewa. Produk pembiayaan dengan prinsip bagi hasil biasanya menggunakan akad mudarabah dan musharakah. Pembiayaan dengan prinsip jual beli biasanya menggunakan akad murabahah sedangkan pembiayaan dengan prinsip sewa menggunakan akad ijarah (Faqih, 2017).

Pada PT. Bank BRI Syariah KCP Ponorogo, produk pembiayaan syariah meliputi, KPR BRI Syariah iB adalah pembiayaan untuk membantu nasabah dalam kepemilikan rumah dengan prinsip jual beli (Murabahah) dan IMBT. Pembiayaan KPR BRI Syariah iB bertujuan untuk berbagai keperluan seperti pembelian rumah, apartemen, ruko, rukan, tanah kavling, pembangunan serta renovasi.

Kedua, KKB BRiSyariah iB adalah produk jual-beli yang menggunakan sistem murabahah, yaitu akad jual beli barang dengan menyatakan harga perolehan dan keuntungan (margin) yang kemudian disepakati oleh bank dan nasabah sebagai harga jual (fixed margin). Produk ini mempunyai keunggulan yaitu menggunakan sistem shari'ah, jangka waktu maksimal 5 tahun, cicilan tetap dan meringankan selama jangka waktu serta bebas pinalti untuk pelunasan sebelum jatuh tempo. Ketiga, Produk Pembiayaan Umrah BRISyariah iB mengunakan prinsip akad jual beli manfaat/jasa (ijarah Multijasa).

Banyaknya kritik tajam tentang bank syariah mengisyaratkan bahwa bank syariah dianggap belum sepenuhnya melaksanakan ketentuan syariah. Standar yang dipakai pun berbeda-beda. Seorang ulama kontemporer, Al-Tahir ibn 'Ashur (w. 1393 H) yang menguasai Usul Fiqh melalui karyanya berjudul Maqașid al-Shariah al-Islamiyah, memiliki gagasan maqasid al-shari 'ah khusus dalam bidang hukum niaga atau transaksi pertukaran harta, yaitu: sirkulasi (al-rawaj), transparansi, kekuatan hukum, perlindungan (preservasi), dan keadilan (ibn 'Ashur, 2001a). Kelima maqașid al-shariah khusus dalam transaksi pertukaran harta ini menurut Ibn 'Āshūr merupakan rujukan sah-tidaknya suatu akad muamalah dan ketentuanketentuan teknis dari akad tersebut. Suatu akad dianggap sah apabila kelima maqașid alshari'ah yang dimaksud itu terpenuhi, apabila salah satu maqașid tidak terpenuhi maka akad tersebut dianggap tidak sah (ibn 'Ashur, 2001). 
JoIE: Journal of Islamic Economics I Mohammad Ridwan

P-ISSN: $2807-7377$

E-ISSN: 2807-7091

Konsepsi maqasid al-shari'ah khusus tentang transaksi pertukaran harta dengan istilah maqasid al-tasarrufat al-maliyyah (ibn 'Ashur, 2001) yang digagas oleh al-Tahir ibn 'Ashur sangat relevan untuk dapat dikembangkan menjadi assesment yang dapat menilai produk pembiayaan di perbankan syariah. Oleh karena itu, pengembangan asessment bank syariah berdasarkan maqasid al-shari'ah gagasan al-Tahir ibn 'Ashur menjadi sangat urgent, karena banyaknya kritik terhadap bank syariah dianggap tidak patuh pada ketentuan syariah dalam menjalankan sebagian praktik pembiayaan. Maka dari sinilah penulis bermaksud untuk menuangkan tulisan dalam bentuk tesis

\section{TINJAUAN LITERATUR}

\section{Maqasid al-Shari'ah}

Maqasid al-Shari'ah merupakan kata majemuk (idafi) yang terdiri dari dua kata yaitu maqasid dan al-shari'ah. Secara bahasa, maqasid merupakan bentuk jama' (plural) dari kata maqsud. yang terbentuk dari huruf qaf, sad dan dal, yang berarti kesengajaan atau tujuan. Sedangkan kata al-shari'ah berasal dari kata shara'a yashra'u shar'an yang berarti membuat shari'at atau undang-undang, menerangkan dan menyatakan. Dikatakan juga shara'a lahum shar'an berarti ia telah menunjukkan jalan kepada mereka atau mempunyai makna sanna yang berarti menunjukkan jalan atau peraturan.

Sedangkan shari'ah menurut istilah ada beberapa pendapat. Menurut Asaf A.A. Fyzee, shari'ah adalah canon law of Islam, yaitu keseluruhan perintah Allah yang berupa nasnas. Sedangkan Satria Effendi menjelaskan bahwa shari'ah adalah al-nusus al-muqaddasah yaitu nas yang suci yang terdapat dalam al-Qur'an dan al-Hadith al-Mutawatirah, yang belum tercampuri oleh pemahaman manusia. Sehingga cakupan shari'ah ini meliputi bidang i'tiqadiyyah, 'amaliyah dan khuluqiyah. Akan tetapi menurut ulama mutaakhirin telah terjadi penyempitan makna shari'ah. Mahmud Syaltut menguraikan tentang makna shari'ah, bahwa shari'ah adalah hukum-hukum dan tata aturan yang dishari'atkan oleh Allah untuk hambahamba-Nya agar dipedomani oleh manusia dalam mengatur hubungan dengan Tuhan, dengan sesama manusia, dengan alam dan seluruh kehidupan. Sedangkan al-Sayis menjelaskan bahwa shari'ah adalah hukum-hukum yang diberikan oleh Tuhan untuk hamba-hamba-Nya agar mereka percaya dan mengamalkanya demi kepentingan mereka di dunia dan akhirat.

Ketika kita berbicara maqasid al-shari'ah sebagai salah satu disiplin ilmu tertentu yang independen, maka tidak akan dijumpai definisi yang kongkrit dan komprehensif yang diberikan oleh ulama-ulama klasik, sehingga akan didapati beraneka ragam versi definisi yang 
JoIE: Journal of Islamic Economics I Mohammad Ridwan

P-ISSN: $2807-7377$

E-ISSN: 2807-7091

berbeda satu sama lain, meskipun kesemuanya berangkat dari titik tolak yang hampir sama. Oleh karena itu, kebanyakan definisi maqasid al-shari'ah yang didapati sekarang ini lebih banyak dikemukakan oleh ulama-ulama kontemporer, seperti al-Tahir ibn 'Ashur yang membagi maqasid al-shari'ah menjadi dua bagian. Yaitu maqasid al-shari'ah al- 'ammah dan maqasid al-shari'ah al-khassah. Bagian pertama beliau maksudkan sebagai hikmah, dan rahasia serta tujuan diturunkannya shari'ah secara umum yang meliputi seluruh aspek shari'at dengan tanpa mengkhususkan diri pada satu bidang tertentu. Sementara untuk bagian kedua beliau maksudkan sebagai seperangkat metode tertentu yang dikehendaki oleh al-shari' dalam rangka merealisasikan kemaslahatan dengan mengkhususkannya pada satu bidang dari bidang-bidang shari'at yang ada, misalnya dalam bidang ekonomi, hukum keluarga. Sedangkan menurut 'Allal al-Fasi adalah metode untuk mengetahui tujuan pensyari'atan sebuah hukum untuk menjamin kemaslahatan dan mencegah kemafsadatan yang mengandung kemaslahatan untuk manusia.

Ulama usul al-fiqh sepakat bahwa maqasid al-shari'ah merupakan tujuan-tujuan akhir yang harus direalisasikan dengan pengaplikasian shari'at. Pengaplikasian shari'at di dalam kehidupan nyata dimaksud untuk menciptakan kemaslahatan atau kebaikan para makhluk di dunia, yang kemudian berimbas pada kemaslahatan atau kebaikan di akhirat. Adapun ahli usul al-fiqh yang menjelaskan konsep maqasid al-shari'ah secara khusus, sistematis dan jelas adalah Abu Ishaq al-Shatibi (wafat $790 \mathrm{H}$ ) pada pertengahan abad ke-7, dari kalangan madhab Maliki. Melalui karya beliau dengan judul al-Muwafaqat beliau menyatakan secara tegas bahwa tujuan Allah SWT dalam mensyari'atkan hukum-Nya adalah untuk kebaikan manusia baik di dunia maupun di akhirat. Oleh karena itu, taklif dalam bidang hukum harus bermuara pada tujuan hukum tersebut. Menurutnya maslahat adalah memelihara lima aspek pokok, yaitu agama, jiwa, akal, keturunan dan harta. Beliau juga membedakan peringkat maslahah menjadi tiga kategori, yaitu daruriyyat, hajiyyat dan tatimmat atau tahsiniyyat. Pada abad ke-20 Masehi, Muhammad al-Tahir ibn 'Ashur (1879-1973M) dari Tunisia dianggap sebagai tokoh maqasid al-shari'ah kontemporer setelah al-Shatibi. Beliau telah mampu memisahkan kajian maqasid al-shari'ah dari kajian usul al-fiqh, yang sebelumnya merupakan bagian dari usul al-fiqh (Ibn "Ashur, 2001).

\section{Muhammad al-Tahir ibn 'Ashur}

Nama lengkap beliau adalah Muhammad al-Tahir ibn Muhammad ibn Muhammad alTahir ibn Shekh Muhammad al-Syadzili ibn al-Alim Abdul Qadir ibn al-Alim al-Zahid alWali al-Salih Shekh Muhammad ibn Ashur. Muhammad al-Tahir ibn 'Ashur dilahirkan di 
JoIE: Journal of Islamic Economics I Mohammad Ridwan

P-ISSN: $2807-7377$

E-ISSN: 2807-7091

kota Al-Marasyi, yaitu kota Tunisia pada bulan Jumadil al-Ula tahun $1298 \mathrm{H}$. bertepatan dengan bulan September tahun 1879 M. Ibn 'Ashur wafat pada tanggal 12 Rajab 1393 H. atau 12 Oktober 1973 M. sebelum salat Maghrib setelah sebelumnya beliau merasakan sakit ringan saat melaksanakan s\}alat 'Ashar. Beliau merupakam keturunan keluarga ulama besar yang dirunut akan sampai pada ulama Maliki Andalusia. Kakek dari ayah Ibn 'Ashur juga bernama Muhammad al-Tahir Ibn 'Ashur, beliau lahir pada tahun $1230 \mathrm{H}$. dan terkenal dengan sebutan Ibn 'Ashur. Beliau pernah menjabat pada kedudukan-kedudukan penting seperti, qadi dan mufti, pengawas waqaf, dewan pengajar, dan anggota majlis shura.

Muhammad al-Ṭāhir ibn 'Āshūr dilahirkan di distrik La Marsa, merupakan kawasan yang indah di utara kota Tunis, di pantai timur-laut Mediterania, sebuah kawasan yang menjadi buah bibir para penyair dalam karya-karya mereka. Ia tumbuh dalam lingkungan seperti ini, di bawah asuhan ayahnya yang sangat berharap putranya dapat mewarisi keilmuan kakeknya Muhammad al-Ṭāhir ibn 'Āshūr pertama, serta kakek dari pihak ibu yang juga berharap cucunya ini kelak dapat menjadi penggantinya.

Muhammad al-Ṭāhir ibn 'Āshūr tumbuh di tengah keluarga yang memiliki tradisi keilmuan yang baik, kakek dari pihak ayah adalah Hakim Agung sedangkan kakek dari pihak ibu Wazir Agung. Ia sudah menghafal al-Qur'an dengan baik sejak kecil seperti layaknya anak-anak seusianya di masa itu, kemudian menghafal sejumlah matan-matan ilmiah di kuttāb guna mempersiapkan diri untuk menempuh pendidikan di Perguruan al-Zaitunah, seperti matn al-Ajurumiyah, matn ibn 'Ashir dan lain sebagainya. Di usianya yang ke-tujuh tahun (1886 M) dia masuk ke perguruan Zaitunah dan menempuh pendidikan dasar di sana selama tujuh tahun, kemudian melanjutkan ke jenjang yang lebih tinggi di institusi yang sama.

Pada 1899 Masehi, Ibn 'Ashur dipercaya untuk mengajar di Universitas Zaitunah. Selain itu, beliau juga dipercaya mengajar di Perguruan Tinggi Sadiqiyyah sejak tahun 1904. Pada tahun 1932, Ibn 'Ashur ditetapkan sebagai Shaikh al-Islam al-Maliki di Universitas Zaitunah sekaligus Rektor di Universitas tersebut. Selain dalam bidang pendidikan, Ibn 'Ashur juga berkarir dalam bidang peradilan, sejak tahun 1911 beliau bertugas menjadi Hakim, dan dua puluh dua tahun kemudian beliau ditetapkan sebagai mufti dalam mazhab Maliki.

Ibn 'Ashur termasuk ilmuwan muslim yang prolifik yaitu produktif dalam berkarya. Di antara karyanya adalah Tafsir al-Tahrir wa al-Tanwir, Maqasid al-Shari'ah alIslamiyyah, Usul al-Nizam al-Ijtima'iy fi al-Islam, Alaysa al-Subh bi Qarib, al-Waqf wa Asaruh fi al-Islam, Kashf al-Mu'tiy min al-Ma'aniy wa al-Alfaz al Waqi'ah fi al-Muwatta', 
JoIE: Journal of Islamic Economics I Mohammad Ridwan

P-ISSN: $2807-7377$

E-ISSN: 2807-7091

al-Tawdih wa al-Tashih fi Usul al-Fiqh, dan masih banyak lagi karya lainnya baik dalam bidang Islamic studies, sastra, Bahasa, maupun sejarah (Ibn “Ashur, 2001).

\section{Maqasid Tasarrufat al-Maliyyah}

Maqasid Tasarrufat al-Maliyyah termasuk ke dalam maqasid al shari'ah al khassah perspektif Muhammad al-Tahir ibn 'Ashur. Menurut Ibn 'Āshūr, harta atau kekayaan adalah segala sesuatu yang dapat dimanfaatkan oleh individu, kelompok individua atau masyarakat umum secara langsung maupun tidak langsung untuk mewujudkan kemaslahatan dalam berbagai keadaan, waktu, dan kebutuhan. Harta bisa bernilai kekayaan jika memenuhi lima kriteria yaitu dapat disimpan dalam waktu yang lama, diminati banyak orang, dapat dipindahtangankan, jumlahnya terbatas, diperoleh melalui usaha sendiri ataupun pemilik sebelumnya. Kekayaan dapat bersumber dari tamalluk (kepemilikan), dan takassub (penghasilan). Tamalluk atau milkiyyah adalah penguasaan terhadap sesuatu yang berfungsi sebagai pemenuh kebutuhan secara langsung atau sebagai alat tukarnya. Sedangkan takassub adalah usaha untuk mendapatkan suatu pemenuh kebutuhan tersebut melalui pekerjaan fisik atau negosiasi yang berhubungan dengan pihak lain. Semua bentuk akad muamalah berkaitan dengan salah satu dari tamalluk dan takassub ini. Ibn 'Āshūr menjelaskan lima maqasid alsari'ah khusus dalam tata niaga atau perputaran kekayaan, yaitu: al-rawaj (sirkulasi), transparansi, perlindungan terhadap harta (preservasi), kepastian hukum atas kepemilikan, dan keadilan (Ibn "Ashur, 2001).

Al-Rawaj secara etimologi berarti lari, laku, beredar dan tersedia. al-Rawaj dalam konteks ini mempunyai arti terdistribusikannya harta dengan cara-cara yang sah kepada sebanyak mungkin orang di kalangan umat, tidak terbatas pada kalangan tertentu saja. Menurut ibn 'Ashur, al-rawaj sebagai maqasid al-shari'ah dalam muamalah dipahami dari nas-nas yang mendorong secara siginifikan supaya transaksi pertukaran harta yang dilakukan dapat lebih masif dan luas. Disimpulkan demikian adalah karena muamalah merupakan cara utama terdistribusikannya harta kekayaan dari satu tangan ke tangan yang lain. Hal ini kemudian diperkuat oleh hasil analisis terhadap sejumlah ketentuan hukum muamalah dan pemberdayaan harta kekayaan.

Sejumlah nas yang mendorong muamalah harta kekayaan terselenggara secara masif dan seluas-luasnya dengan pendekatan yang bervariasi, antara lain: (1) Pembolehan transaksi jual beli dan sejenisnya dalam pelaksanaan ibadah haji yang dalam tradisi jahiliyah dianggap suatu kemungkaran. (2) Anjuran untuk tetap produktif sekalipun dalam situasi yang tidak kondusif, dalam sabda Rasulullah: 
JoIE: Journal of Islamic Economics I Mohammad Ridwan

P-ISSN: $2807-7377$

E-ISSN: 2807-7091

Sejumlah ketentuan hukum muamalah menurut Ibn 'Āshūr terindikasi menguatkan maqas\}id sirkulasi. Diperbolehkannya berbagai bentuk akad dalam muamalah itu sendiri adalah di antaranya. Selain itu, berbagai kemudahan yang diberikan dalam sejumlah bentuk muamalah seperti pengesahan beberapa akad yang mengandung unsur gharar yang ringan seperti akad salam dan muzara'ah, ketentuan bahwa akad muamalah berlaku dan mengikat dengan segera kecuali jika disertai syarat-syarat tertentu yang disepakati, seperti hukum waris dalam Islam yang menjadikan harta dari pewaris terbagi pada lebih banyak orang termasuk ahli waris yang mana pada masa jahiliah tidak mendapatkan hak sama sekali, hak pemilik harta untuk berwasiat sepertiga atau kurang dari hartanya sehingga distribusi harta peninggalan tidak terbatas pada ahli waris semata, perintah untuk menginfaqkan harta baik yang sifatnya wajib maupun anjuran, dan kehalalan membelanjakan harta untuk kebutuhan sekunder bahkan tersier sebagai hukum dasar sepanjang tidak mubazir. (1) Transparansi. Transparansi atau kejelasan harta adalah harta yang menjadi objek kekayaan yang dapat diketahui dengan jelas wujud dan batasannya sehingga terhindar dari sengketa yang disebabkan oleh klaim pihak lain atas harta yang dimaksud. Dalil yang dijelaskan Ibn 'Ashur untuk maqașid ini adalah syariat kesaksian dan rahn atau agunan dalam hutang piutang. Akad muamalah terhadap harta kekayaan disyariatkan untuk melindungi harta yang menjadi objek kekayaan agar tidak berpindah tangan dengan cara-cara yang batil dan mengintimidasi pemiliknya.

Oleh karena itu, setiap individu wajib menghormati hak milik orang lain, sehingga perbuatan merusak milik orang lain disanksi dengan kewajiban mengganti tanpa memperhatikan niat sengaja atau tidaknya perbuatan itu dilakukan. Perlindungan dimaksud tidak terbatas pada kekayaan pribadi seperti tersebut dalam nas-nas di atas tetapi mencakup dan berlaku juga untuk kekayaan kolektif umat, oleh karena itu pemimpin atau yang berwewenang berkewajiban menetapkan kebijakan yang dapat memberikan perlindungan terhadap harta kekayaan umat baik dalam transaksi internal maupun dengan pihak luar.

Kekuatan hukum pada transaksi dimaksud bertujuan untuk: melindungi hak eksklusif pemilik harta untuk memanfaatkan dan mengambil keuntungan dari harta yang menjadi objek kekayaan; menjamin kebebasan yang bersangkutan untuk mengelola dan memberdayakan harta kekayaan secara sah untuk mendapatkan manfaat dan keuntungan yang diinginkan; serta memastikan bahwa hak eksklusif dan kebebasan mengelola sebagaimana dimaksud tidak gugur atau berpindah tangan tanpa izinnya kecuali jika merugikan pihak lain atau kepentingan umum. 
JoIE: Journal of Islamic Economics I Mohammad Ridwan

P-ISSN: 2807-7377

E-ISSN: 2807-7091

Keadilan dalam berharta atau al-'adalah fi al-mal maksudnya ialah bahwa pemerolehan harta kekayaan tidak merugikan pihak lain dan kepentingan umum, baik pemerolehan yang berupa imbalan dari suatu kerja yang dilakukan, atau kompensansi dari harta yang diberikan, atau donasi, atau warisan. Privasi pemilik harta dalam memanfaatkan hartanya pada kondisi tertentu akan dibatasi jika merugikan pihak lain baik individu maupun umum.

Menurut Ibn 'Āsyūr maksud ini dipahami dari larangan terhadap sejumlah transaksi yang syarat dan rukunnya telah terpenuhi semisal talaqqi rukban dan ihtikar. Talaqqi rukban ialah mencegat pedagang dari luar daerah yang umumnya tidak mengetahui secara pasti harga komoditi yang dibawanya, dan larangan ihtikar, yaitu membeli barang kemudian menimbunnya supaya pasar mengalami kelangkaan pasokan kemudian harganya melonjak. Privasi pemilik modal untuk memperoleh manfaat dan keuntungan dengan modal yang dimilikinya dalam kedua bentuk muamalah terlarang tersebut dibatasi; demi kemaslahatan umum cara-cara tertentu yang secara teori dapat memberikan keuntungan lebih besar bagi individu tidak dibenarkan (Ibn "Ashur, 2001).

Kelima maqasid al-shari'ah khusus dalam muamalah dengan objek harta kekayaan ini menurut Ibn 'Āshūr merupakan rujukan sah-tidak sahnya suatu akad dan ketentuan-ketentuan teknis yang menjadi bagian akad tersebut. Suatu akad dipandang sah bilamana kelima maqasid al-shara'ah dimaksud terpenuhi, jika salah satu maqas $\}$ id tidak terpenuhi maka akad tersebut pada dasarnya tidak sah. Namun demikian ketidakterpenuhan tersebut dapat ditoleransi dengan tetap melegalkan akad dimaksud bilamana maslahah melegitimasikan akad dimaksud lebih besar ketimbang menjadi faktor ketidaksempurnaan maqasid untuk mendeligitimasi akad tersebut (Ibn "Ashur, 2001).

\section{Al-Ijarah al-Muntahiyah bi al-Tamlik}

Menurut fatwa Dewan Syaariah Nasional-Majelis Ulama Indonesia no. 9 tahun 2000, ija $>$ rah adalah akad pemindahan hak guna (manfaat) atas suatu barang dan/atau jasa dalam waktu tertentu dengan pembayaran sewa (ujrah). Sewa menyewa dalam Bahasa Arab berasal dari kata اجري yang sinonimnya اكري artinya menyewakan. al-Fikri mengartikan ija>rah menurut bahasa dengan: الكراة أو بيع المنفعة yang artinya: sewa-menyewa atau jual beli manfaat. Sedangkan Sayid Sabiq mengemukakan:

$$
\text { الإجارة مشتقة من الأجر وهو العوض, ومنه سمي الثواب أجرا }
$$

al-Ijarah diambil dari kata "al-Ajr" yang artinya 'iwad (imbalan), dari pengertian ini pahala (thawab) dinamakan ajr (upah/pahala) (Ibn "Ashur, 2001). 
JoIE: Journal of Islamic Economics I Mohammad Ridwan

P-ISSN: 2807-7377

E-ISSN: 2807-7091

Secara istilah, ijarah adalah akad pemindahan hak guna atas barang atau jasa, melalui pembayaran upah (ujrah) sewa, tanpa diikuti dengan pemindahan kepemilikan atas barang yang menjadi objek sewa tersebut. Sedangkan al-Ijarah al-Muntahiyah bi al-Tamlik dalam fatwa DSN-MUI no. 27 tahun 2002 adalah akad sewa-menyewa barang yang disertai dengan opsi pemindahan hak milik atas barang yang disewa kepada penyewa setelah selesai masa sewa.

Menurut Kamus Ekonomi Syariah, al-Ijarah al-Muntahiyah bi al-Tamlik adalah ijarah dengan janji yang mengikat pihak yang menyewakan untuk menjadikan kepemilikan kepada pihak penyewa. Menurut Ascarya al-Ijarah al-Muntahiyah bi al-Tamlik adalah akad penyaluran dana untuk pemindahan hak guna (manfaat) atas suatu barang dalam waktu tertentu dengan pembayaran sewa (ujrah) antara perusahaan pembiayaan sebagai pemberi sewa dengan penyewa disertai opsi pemindahan hak milik atas barang yang disewa kepada penyewa setelah selesai masa sewa. Dasar Hukum Ijarah adalah Al-Qur'an surat Al-Thalaq ayat 6 dan Hadith.

Rukun Ijarah dan al-Ijarah al-Muntahiyah bi al-Tamlik. Menurut Dewan Syariah Nasional no. 9 tahun 2000, rukun dan syarat ijarah adalah:

a) Sighat Ijarah, yaitu ijab dan qabul berupa pernyataan dari kedua belah pihak yang berakad (berkontrak), baik secara verbal atau dalam bentuk lain.

b) Pihak-pihak yang berakad, terdiri atas pemberi sewa/pemberi jasa dan penyewa/pengguna jasa.

c) Objek akad ijarah, yaitu:

manfaat barang dan sewa; atau manfaat jasa dan upah.

Menurut 'ulama Hanafiyah rukun ijarah adalah ijab dan qabul, Akan tetapi menurut jumhur ulama' rukun Ijarah ada empat:

a) Aqid (orang yang berakad yaitu penyewa dan yang menyewakan)

b) Sighat (Ijab Qabul)

c) Ujrah (Upah)

d) Manfaat

Namun, menurut ulama madhab Hanafi, rukun yang dikemukakan oleh jumhur ulama di atas adalah bukan rukun melainkan termasuk dalam kategori syarat (Sulhan dan Siswanto, 2008).

\section{METODE PENELITIAN}


JoIE: Journal of Islamic Economics I Mohammad Ridwan

P-ISSN: 2807-7377

E-ISSN: 2807-7091

Metode penelitian yang digunakan dalam penelitian ini adalah metode penelitian kualitatif. Penelitian ini bersifat deskriptif karena berusaha mendiskripsikan dan menggambarkan fenomena mekanisme pembiayaan IMBT di BRI Syariah Kantor Cabang Pembantu Ponorogo untuk mencari dan menemukan makna kesesuaian akad IMBT terhadap maqasid al-tasarrufat al maliyah Muhammad al-Tahir ibn 'Ashur (Yusuf, 2014).

Pendekatan dalam penelitian ini menggunakan pendekatan sosiologis yang berarti fenomena kepatuhan bank syariah didekati dengan teori-teori sosiologi untuk mengungkap motivasi intrinsik dan ekstrinsik dari perilaku patuh atau tidak patuhnya bank syariah (Supiana, 2017). Pendekatan sosiologis yang digunakan dalam penelitian ini menggunakan sub-pendekatan interaksionisme yang memusatkan perhatian pada interaksi antara individu dan kelompok melalui simbol-simbol dan isyarat yang dianggap memiliki makna khusus jika dikaitkan dengan suatu kejadian tertentu (Susanto, 2016). Jenis data yang digunakan dalam penelitian ini adalah data kualitatif dari kata-kata dan tindakan subyek penelitian yaitu BRI Syariah Kantor Cabang Pembantu Ponorogo yang diamati atau diwawancarai sebagai sumber informasi utama.

Pengumpulan data dalam penelitian ini melalui penelitian lapangan (field research) dengan teknik pengumpulan dokumentasi dan wawancara terencana tidak terstruktur. Sedangkan teknik pemeriksaan data dalam penelitian ini melalui uji kredibilitas dan uji dependibilitas. Analisis data kualitatif menggunakan analisis Miles dan Huberman dimana analisis data kualitatif dilakukan secara interaktif dan berlangsung secara terus menerus sampai tuntas dengan kegiatan data reducation, data display, dan conclusion (Sugiyono, 2008).

\section{HASIL DAN PEMBAHASAN}

\section{Sirkulasi (al-Rawaj)}

Sirkulasi (al-rawaj) merupakan bagian dari tujuan syariah (maqaṣid al-sharī'ah) agar akad transaksi pertukaran harta dapat menciptakan distribusi atau perpindahan harta diantara manusia dengan cara-cara yang hak (ibn 'Ashur, 2001). Tujuan akad dalam jual beli adalah memindahkan kepemilikan atas suatu benda dengan imbalan sebagai manifestasi riil yaitu pertukaran yang timbal balik dan merupakan sumber kekuatan mengikat bagi penjual untuk memindahkan kepemilikan atas barang kepada pembeli dan bagi pembeli untuk melakukan pembayaran harga kepada penjual. 
JoIE: Journal of Islamic Economics I Mohammad Ridwan

P-ISSN: $2807-7377$

E-ISSN: 2807-7091

Dimensi dari konstruk sirkulasi (ar-rawaj) adalah 1) pemindahan hak milik atas barang kepada pembeli, dan (2) pembayaran harga oleh pembeli kepada penjual. Elemen yang dapat diamati dan terukur dari dimensi pemindahan hak milik atas barang kepada penyewa adalah: (a) Perpindahan hak milik, (b) Pengalihan kepemilikan, dan (c) Peralihan hak dan kewajiban atas barang. Sedangkan elemen yang dapat diamati dan terukur dari dimensi pembayaran harga oleh pembeli kepada penjual adalah: (a) Ketentuan harga, dan (b) Mekanisme pembayaran.

\section{Transparansi}

Menurut Ibn 'Ashur, transparansi merupakan bagian dari tujuan syariah (maqașid alshari'ah) agar akad transaksi pertukaran harta terhindar dari bahaya perselisihan dan pertengkaran, maka harus ada kejelasan bentuk atau wujud dan batasan harta yang ditransaksikan. Konstruk ini jika diterapkan pada akad transaksi pertukaran harta merupakan objek akad (mah al al-aqd) yaitu obyek yang menjadi sasaran yang hendak dicapai oleh para pihak melalui penutupan akad. Objek akad dapat berupa benda, manfaat benda, jasa atau pekerjaan, atau suatu yang lain yang tidak bertentangan dengan syariah. Objek akad memiliki syarat yang harus dipenuhi oleh pelaku akad, yaitu: dapat diserahkan atau dapat dilaksanakan, harus tertentu atau dapat ditentukan, dan dapat ditransaksikan menurut shara'.

Maka dimensi dari konstruk transparansi adalah: (1) objek dapat diserahkan, (2) objek 'aqad harus tertentu atau dapat ditentukan, dan (3) objek akad dapat ditransaksikan menurut shara'. Elemen yang dapat diamati dan terukur dari dimensi objek dapat diserahkan adalah objek dalam penguasaan pemberi sewa. Sedangkan elemen yang dapat diamati dan terukur dari dimensi objek akad harus tertentu atau dapat ditentukan adalah: (a) manfaat/jasa, dan (b) manfaat yang spesifik. Sedangkan elemen yang dapat diamati dan terukur dari dimensi objek akad dapat ditransaksikan menurut shara' adalah: objek sesuai dengan ketentuan shariah.

\section{Kekuatan Hukum}

Kekuatan hukum merupakan bagian dari tujuan syariah (maqașid al-shari'ah) agar akad transaksi pertukaran harta memberikan kekuatan hukum terhadap pemindahan kepemilikan harta diantara pihak yang bertransaksi. Transaksi pertukaran harta agar memiliki legalitas yang kuat membutuhkan akad. akad sendiri adalah pertemuan kehendak para pihak dan kehendak itu diungkapkan melalui pernyataan kehendak yang berupa ucapan atau bentuk ungkapan lain dari masing-masing pihak. Artinya, dalam akad membutuhkan yang namanya para pihak yang membuat akad (al- 'aqidain) yang memenuhi syarat dan pernyataan kehendak (sighat al-'aqd) yang memenuhi syarat. 
JoIE: Journal of Islamic Economics I Mohammad Ridwan

P-ISSN: 2807-7377

E-ISSN: 2807-7091

Dimensi dari konstruk kekuatan hukum adalah: (1) para pihak yang memenuhi syarat, dan (2) pernyataan kehendak yang memenuhi syarat. Elemen yang dapat diamati dan terukur dari dimensi para pihak yang memenuhi syarat adalah: Memiliki kapasitas hukum. Sedangkan elemen yang dapat diamati dan terukur dari dimensi pernyataan kehendak yang memenuhi syarat adalah: (a) Tercapainya kesepakatan atau kata sepakat, (b) kesatuan majelis akad, (c) Berdasarkan keridhoan, dan (d) Tidak mengandung unsur cacat kehendak.

\section{Preservasi}

Preservasi merupakan bagian dari tujuan syariah (maqașid al-shari'ah) agar akad transaksi pertukaran harta dapat menciptakan perlindungan terhadap harta dari pemindahan kepemilikan secara batil. Harta agar terlindungi dari transfer kepemilikan secara batil tergantung pada kekuatan perjanjian yang mengikat para pihak untuk memenuhi dan tanggungjawab terhadap akad.

Maka dimensi dari konstruk preservasi adalah: (1) Kewajiban memenuhi akad, dan (2) Tanggungjawab terhadap akad. Elemen yang dapat diamati dan terukur dari dimensi kewajiban memenuhi akad adalah: Para pihak terikat ketentuan dalam kontrak. Sedangkan elemen yang dapat diamati dan terukur dari dimensi tanggungjawab terhadap akad adalah: (a) ketentuan ganti rugi, (b) Penyelesaian sengketa melalui musyarawah, dan (c) penyelesaian sengketa melalui pengadilan.

\section{Keadilan}

Menurut al-Tahir bin 'Ashur, keadilan merupakan bagian dari tujuan syariah (maqașid al-shari'ah) agar akad transaksi pertukaran harta tidak merugikan pihak lain dalam hal pemerolehan harta. Agar tidak merugikan pihak lain dalam transaksi pertukaran harta harus dilandasi dengan asas keseimbangan dan asas keadilan. Asas keseimbangan tercermin dari keseimbangan para pihak dalam bertransaksi dan keseimbangan dalam memikul risiko. Sedangkan asas keadilan bertumpu pada kesempatan bagi para pihak untuk melakukan negoisasi mengenai klausul akad.

Maka dimensi dari konstruk keadilan adalah: (1) Keseimbangan dalam transaksi, (2) Keseimbangan memikul risiko, dan (3) Kesempatan melakukan negoisasi klausul akad. Elemen yang dapat diamati dan terukur dari dimensi keseimbangan dalam transaksi adalah: Saling menguntungkan. Elemen yang dapat diamati dan terukur dari dimensi keseimbangan memikul risiko adalah kesetaraan hak dan kewajiban. Sedangkan elemen yang dapat diamati dan terukur dari dimensi kesempatan melakukan negoisasi klausul akad adalah: (a) 
JoIE: Journal of Islamic Economics I Mohammad Ridwan

P-ISSN: $2807-7377$

E-ISSN: 2807-7091

kesempatan bermusyawarah, dan (b) Penyelesaian permasalahan force majeur secara musyawarah.

Setelah peneliti menjelaskan praktik pembiayaan IMBT yang dijalankan oleh BRI Syariah KCP Ponorogo dan menganalisis bagaimana kesesuaian praktik tersebut terhadap standar produk yang ditetapkan Dewan Syariah Nasional, selanjutnya peneliti memberikan nilai dan skor indikator untuk masing-masing elemen dari maqasid al-tasarrufat al-maliyyah yaitu: sirkulasi, transparansi, kekuatan hukum, preservasi, dan keadilan. Ringkasan hasil assesmennya adalah sebagai berikut.

Tabel 1. Skor Indikator Elemen Maqasid Al-Tasarrufat Al-Maliyyah

\begin{tabular}{|c|c|c|c|c|}
\hline Maqasid & Dimensi & Elemen & Nilai & Skor \\
\hline \multirow[t]{5}{*}{ Sirkulasi } & \multirow{3}{*}{$\begin{array}{l}\text { Pemindahan hak milik } \\
\text { barang kepada penyewa }\end{array}$} & Perpindahan hak milik & $\mathrm{B}$ & 3 \\
\hline & & Pengalihan kepemilikan & B & 3 \\
\hline & & $\begin{array}{l}\text { Peralihan hak dan kewajiban } \\
\text { atas barang yang disewa }\end{array}$ & & 2 \\
\hline & \multirow[t]{2}{*}{ Pembayaran ujrah oleh penyewa } & Ketentuan ujrah & B & 3 \\
\hline & & Mekanismen pembayaran & B & 3 \\
\hline & \multicolumn{3}{|l|}{ Total } & 14 \\
\hline \multirow[t]{4}{*}{ Transparansi } & Objek akad dapat diserahkan & \multicolumn{2}{|l|}{$\begin{array}{l}\text { Objek dalam penguasaan } B \\
\text { pemberi sewa }\end{array}$} & 3 \\
\hline & \multirow{2}{*}{\multicolumn{2}{|c|}{$\begin{array}{l}\text { Objek harus berbentuk tertentu Manfaat/ jasa } \\
\text { dan jelas }\end{array}$}} & B & 3 \\
\hline & & & $\mathrm{C}$ & 2 \\
\hline & Objek dapat ditransaksikan & $\begin{array}{l}\text { Sesuai dengan ketentuan } \\
\text { Syariah (yang dibolehkan) }\end{array}$ & $\mathrm{B}$ & 3 \\
\hline
\end{tabular}

\begin{tabular}{|c|c|c|c|}
\hline & Total & & 11 \\
\hline \multirow[t]{5}{*}{$\begin{array}{l}\text { Kekuatan } \\
\text { Hukum }\end{array}$} & \multicolumn{2}{|c|}{$\begin{array}{l}\text { Para pihak harus memenuhi Memiliki kapasitas hukum } \\
\text { syarat }\end{array}$} & 3 \\
\hline & \multirow{4}{*}{$\begin{array}{l}\text { Pernyataan kehendak } \\
\text { memenuhi syarat }\end{array}$} & Tercapainya kesepakatan & 3 \\
\hline & & Kesatuan majelis akad & 4 \\
\hline & & Berdasarkan keridoan & 3 \\
\hline & & $\begin{array}{l}\text { Tidak mengandung unsur B } \\
\text { cacat kehendak }\end{array}$ & 3 \\
\hline & \multicolumn{2}{|l|}{ Total } & 16 \\
\hline \multirow[t]{4}{*}{ Preservasi } & Kewajiban memenuhi akad & $\begin{array}{l}\text { Para pihak terikat ketentuan } B \\
\text { dalam kontrak }\end{array}$ & 3 \\
\hline & \multirow[t]{3}{*}{ Tanggung jawab terhadap akad } & Ketentuan ganti rugi & 3 \\
\hline & & $\begin{array}{l}\text { Penyelesaian sengketa B } \\
\text { melalui musyawarah }\end{array}$ & 3 \\
\hline & & Penyelesaian & 3 \\
\hline
\end{tabular}


JoIE: Journal of Islamic Economics I Mohammad Ridwan

P-ISSN: $2807-7377$

E-ISSN: 2807-7091

melalui pengadilan

\begin{tabular}{|c|c|c|c|}
\hline & Total & & 12 \\
\hline \multirow[t]{4}{*}{ Keadilan } & Keseimbangan dalam transaksi & Saling menguntungkan & 3 \\
\hline & Keseimbangan memikul risiko & $\begin{array}{l}\text { Kesetaraan hak dan C } \\
\text { kewajiban }\end{array}$ & 2 \\
\hline & \multirow{2}{*}{$\begin{array}{l}\text { Kesempatan } \\
\text { negosiasi }\end{array}$} & melakukan Kesempatan bermusyawarah B & 3 \\
\hline & & $\begin{array}{l}\text { Penyelesaian permasalahan B } \\
\text { force majeur secara } \\
\text { musyawarah }\end{array}$ & 3 \\
\hline
\end{tabular}

\section{Total}

Sumber: Data diolah 2021

Berdasarkan tabel hasil ringkasan assesmen terhadap masing-masing elemen maqasid al-tasarufat al-maliyyah di BRI Syariah KCP Ponorogo dapat diketahi jumlah skor indikator untuk masing-masing maqasid: sirkulasi sebesar 14, transparansi sebesar 11, kekuatan hukum sebesar 16, preservasi sebesar 12, dan keadilan sebesar 11. Selanjutnya dapat dihitung skor tertimbang untuk masing-masing maqasid dengan hasil sebagai berikut.

Tabel 2. Skor Tertimbang Masing-masing Maqasid

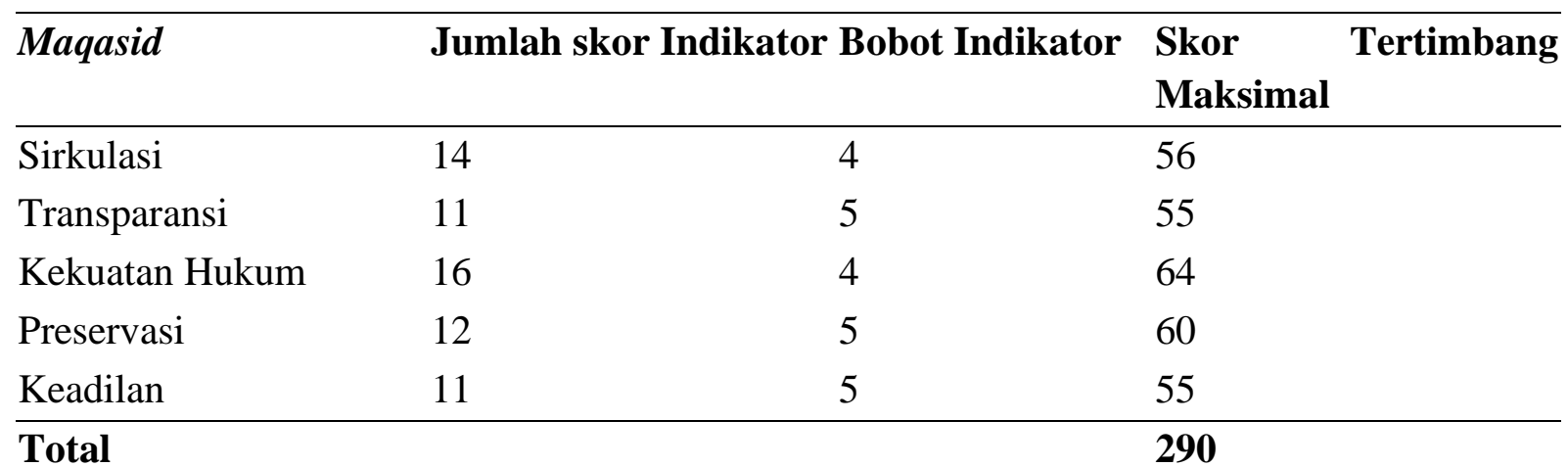

Sumber: data diolah 2021

Berdasarkan tabel hasil skor tertimbang di atas dapat diketahui bahwa BRI Syariah KCP Ponorogo memiliki skor tertimbang untuk masing-masing maqasid sirkulasi sebesar 56, transparansi sebesar 55, kekuatan hukum sebesar 64, preservasi sebesar 60, dan keadilan sebesar 55. Selanjutnya dapat dihitung nilai akhir komponen untuk masing-masing maqasid dengan hasil sebagai berikut.

Tabel 3. Nilai Akhir Komponen Maqasid

\begin{tabular}{|c|c|c|c|c|}
\hline \multirow{2}{*}{ Maqasid } & Skor Tertimbang & & \multirow{2}{*}{$\begin{array}{l}\text { Nilai } \\
\text { Komponen }\end{array}$} & \multirow{2}{*}{ Akhir } \\
\hline & Maksimum & Skor Tertimbang & & \\
\hline Sirkulasi & 80 & 56 & $70 \%$ & \\
\hline Transparansi & 80 & 55 & $68.75 \%$ & \\
\hline
\end{tabular}


JoIE: Journal of Islamic Economics I Mohammad Ridwan

P-ISSN: 2807-7377

E-ISSN: 2807-7091

\begin{tabular}{llll}
\hline Kekuatan Hukum & 80 & 64 & $80 \%$ \\
Preservasi & 80 & 60 & $75 \%$ \\
Keadilan & 80 & 55 & $68.75 \%$ \\
\hline Total & $\mathbf{4 0 0}$ & $\mathbf{2 9 0}$ & - \\
\hline
\end{tabular}

Sumber: Data diolah 2021

Berdasarkan tabel nilai akhir komponen di atas dapat diketahui bahwa BRI Syariah KCP Ponorogo memiliki pencapaian nilai akhir komponen untuk masing-masing maqasid: sirkulasi mencapai 70\%, transparansi mencapai 68.75\%, kekuatan hukum mencapai 80\%, preservasi mencapai 75\%, dan keadilan mencapai 68.75\%. Artinya, pembiayaan IMBT di BRI Syariah KCP Ponorogo telah memenuhi maqasid kekuatan hukum dan preservasi dengan sangat baik. Sedangkan pemenuhan maqasid sirkulasi, transparansi, dan keadilan dalam praktik pembiayaan IMBT yang dijalankan sudah baik. Selanjutnya dapat dihitung skor kesesuaian yang dicapai oleh BRI Syariah KCP Ponorogo dengan rumus sebagai berikut:

\section{Total Skor Kesesuaian $=($ jumlah skor tertimbang/jumlah skor tertimbang maksimum) x $100 \%$}

Jadi total skor kesesuaian BRI Syariah KCP Ponorogo $=(290 / 400) \times 100 \%=72.5 \%$

Berdasarkan perhitungan rumus mencari skor kesesuaian di atas, dapat diketahui total skor BRI Syariah KCP Ponorogo terhadap akad IMBT berdasarkan maqasid al-tasarrufat almaliyyah sebesar 72.5\% dengan kondisi patuh. Deskripsi kesesuaian akad BRI Syariah KCP Ponorogo adalah sebagai berikut:

Tabel 4. Deskripsi kesesuaian akad BRI Syariah KCP Ponorogo

\begin{tabular}{|c|c|c|c|}
\hline Peringkat & Kondisi & Total Skor & Keterangan \\
\hline 1 & $\begin{array}{l}\text { Sangat } \\
\text { Patuh }\end{array}$ & $\geq 75$ & $\begin{array}{l}\text { Kesesuaian bank terhadap akad IMBT sangat sesuai } \\
\text { dengan maqasid al-tasarrufat al-maliyyah }\end{array}$ \\
\hline 2 & Patuh & $50<\mathrm{TS}<75$ & $\begin{array}{l}\text { Kesesuaian bank terhadap akad IMBT sesuai dengan } \\
\text { maqasid al-tasarrufat al-maliyyah }\end{array}$ \\
\hline 3 & $\begin{array}{l}\text { Tidak } \\
\text { Patuh }\end{array}$ & $25<\mathrm{TS}<50$ & $\begin{array}{l}\text { Kesesuaian bank terhadap akad IMBT tidak sesuai } \\
\text { dengan maqasid al-tasarrufat al-maliyyah }\end{array}$ \\
\hline 4 & $\begin{array}{l}\text { Sangat } \\
\text { Tidak } \\
\text { Patuh }\end{array}$ & $\mathrm{TS} \leq 25$ & $\begin{array}{l}\text { Kesesuaian bank terhadap akad IMBT sangat tidak } \\
\text { sesuai dengan maqasid al-tasarrufat al-maliyyah }\end{array}$ \\
\hline
\end{tabular}

Sumber: Data diolah 2021

Berdasarkan tabel di atas dalam hal kepatuhan terhadap aqad IMBT berdasarkan maqasid tasarrufat al-maliyyah mencapai peringkat 2 dengan kondisi patuh artinya akad 
JoIE: Journal of Islamic Economics I Mohammad Ridwan

P-ISSN: $2807-7377$

E-ISSN: 2807-7091

IMBT yang dijalankan oleh BRI Syariah KCP Ponorogo sesuai dengan elemen-elemen dari 5 (lima) maqasid tasarrufat al-maliyyah perspektif al-Tahir ibn 'Ashur.

\section{KESIMPULAN}

Berdasarkan assesmen kesesuaian BRI Syariah Kantor Cabang Pembantu Ponorogo terhadap akad al-Ijarah al-Muntahiyyah bi al-Tamlik (IMBT) berdasarkan maqasid altasrrufat al-maliyyah perspektif al-Tahir ibn 'Ashur menghasilkan tingkat kesesuaian atau kepatuhan sebesar 72.5\% dengan kondisi patuh. Pencapaian 5 (lima) maqasid dalam transaksi pembiayaan IMBT yang ditetapkan oleh al-Tahir ibn 'Ashur adalah sebagai berikut. Pertama, maqasid sirkulasi memperoleh skor tertimbang 56 atau 70\% dari skor tertimbang maksimum. Kedua, maqasid transparansi memperoleh skor tertimbang 55 atau $68.75 \%$ dari skor tertimbang maksimum. Ketiga, maqasid kekuatan hukum memperoleh skor tertimbang 64 atau $80 \%$ dari skot tertimbang maksimum. Keempat, maqasid preservasi memperoleh skor tertimbang 60 atau $75 \%$ dari skor tertimbang maksimum. Kelima, maqasid keadilan memperoleh skor tertimbang 55 atau $68.75 \%$ dari skor tertimbang maksimum.

\section{REFERENSI}

Aditiasari, D. (2019, diakses tanggal Agustus). Hambatan yang Buat Bank Syariah Lambat Berkembang di RI. https://finance.detik.com/moneter/3076959/7-hambatan-yang-buat-banksyariah-lambat berkemb ang-diri

Faqih, A. R. (2017). Bank Syariah, Kontrak Bisnis Syariah dan Penyelesaian Sengketa di Pengadilan. FH UII Press.

ibn 'Ashur, M. al-Tahir. (2001a). Maqasid al-Shari'ah al-Islamiyyah, Tahqiq Muhammad alTahir al-Misawiy. Dar al-Nafais.

ibn 'Ashur, M. al-Tahir. (2001b). Maqasid al-Shari'ah al-Islamiyyah, Tahqiq Muhammad alTahir al-Misawiy. Dar al-Nafais.

ibn 'Ashur, M. al-Tahir. (2001c). Maqasid al-Shari'ah al-Islamiyyah, Tahqiq Muhammad alTahir al-Misawiy. Dar al-Nafais.

Sugiyono. (2008). Metode Penelitian Bisnis (Pendekatan Kuantitatif, Kualitatif dan R\&D. Alfabeta.

Sulhan, M., \& Siswanto, S. (2008). Manajemen Bank: Konvensional dan Syariah. UINMaliki Press.

Supiana. (2017). Metodologi Studi Islam. PT Remaja Rosdakarya. 
JoIE: Journal of Islamic Economics I Mohammad Ridwan

P-ISSN: 2807-7377

E-ISSN: 2807-7091

Susanto, E. (2016). Dimensi Studi Islam Kontemporer. Kencana.

Yusuf, M. (2014). Metode penelitian: Kuantitatif, kualitatif \& penelitian gabungan.

Zen Ibrahim. (2019, Juli 22). Menggugat Bank Syariah, (online). http://www.metro sulawesi.com/article/ menggugat-bank-syariah-0 